*ak RMIS View/Frint Document Cover Sheet tow

This document was retrieved from the Documentation and Records Manaqement (DRM) ISEARCH System. It is intended for Information only and may not be the most recent or updated version. Contact a Document Service Center (see Hanford Info for locations) if you need additional retrieval information.

Accession \#: D196008619

Document \#: SD-WM-SFR-012

Title/Desc:

FUNCTIONAL REQUIREMENTS FOR GAS CHARACTERIZATION SYSTEM COMPUTER SOFTWARE

Pages: 9 


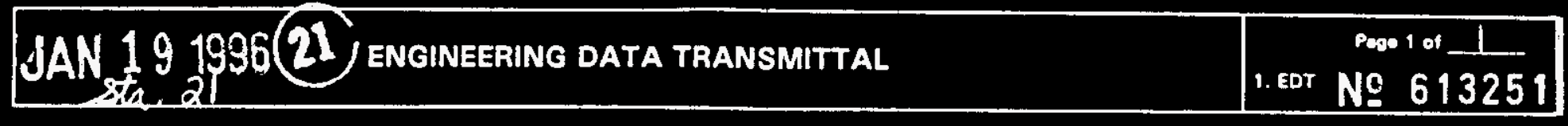

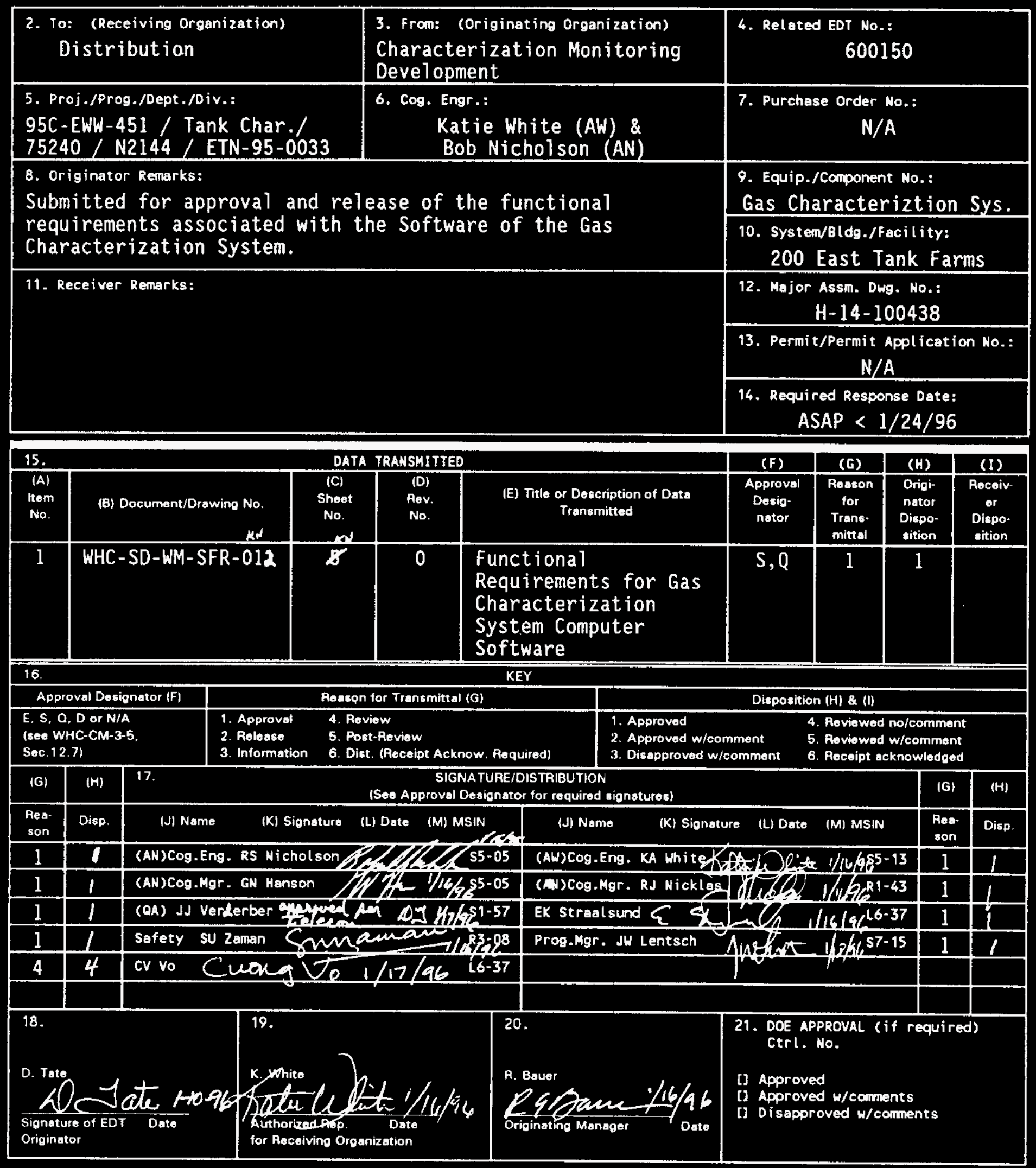

BO-7400-172-2 (04/94) GEF097 
kN

\title{
Functional Requirements for Gas Characterization System Computer Software
}

\author{
Daron Tate
}

Westinghouse Hanford Company, Richland, WA 99352

U.S. Department of Energy Contract DE-AC06-87RL10930

\author{
EDT/ECN: 613251 \\ UC: 506 \\ Org Code: 75240 \\ Charge Code: N2144 \\ B\&R Code: EW3120072 \\ Total Pages: 6
}

Key Words: requirements, software, Gas Characterization System, FTIR, Gas Chromatograph, Hydrogen, Ammonia, Nitrous Oxide, Methane

Abstract: This document provides the Functional Requirements for the Computer Software operating the Gas Characterization System (GCS), which monitors the combustible gasses in the vapor space of selected tanks. Necessary computer functions are defined to support design, testing, operation, and change control. The GCS requires several individual computers to address the control and data acquisition functions of instruments and sensors. These computers are networked for communication, and must multi-task to accommodate operation in parallel.

\footnotetext{
TRADEMARK DISCLAIMER. Reference herein to any specific commercial product, procese, or service by trade name, trademark, manufacturer, or otherwise, does not necessarily constitute or imply its endorsement, recommendation, or favoring by the United States Government or any enency thereof or its contractors or subcontractors.
}

Printed in the United States of Americe. To obtain copies of this document, contact: WHC/BCS Document Control Services, P.O. Box 1970, Mailstop H6-08, Richland WA 99352, Phone (509) 372-2420; Fax (509) 376-4989.

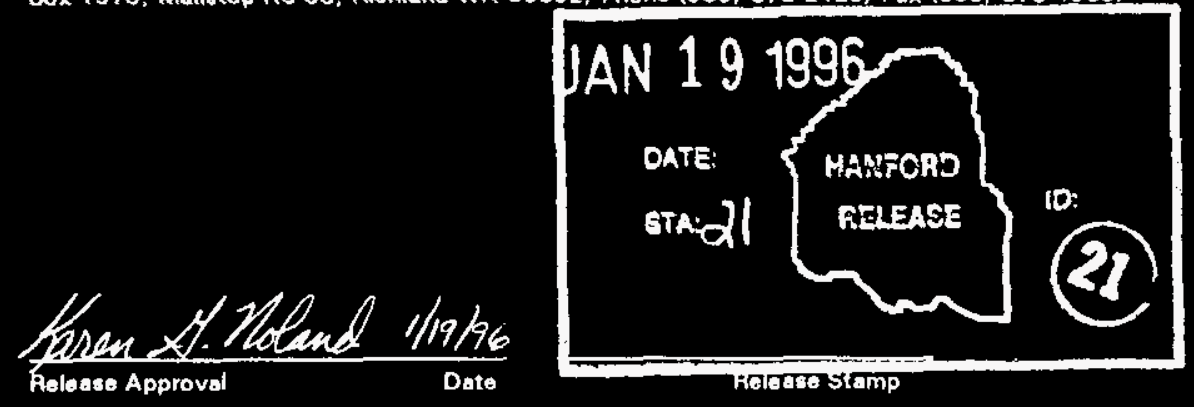

\section{Approved for Public Release}




\title{
FUNCTIONAL REQUIREMENTS FOR
}

\section{GAS CHARACTERIZATION SYSTEM COMPUTER SOFTWARE}

\author{
(WHC-SD-WM-SFR-011)
}

\author{
Prepared by \\ D. D. Tate \\ January 4, 1996 \\ Westinghouse Hanford Company \\ P.O. Box 1970 \\ Richland, Washington 99352
}




\section{SOFTWARE FUNCTIONAL REQUIREMENTS \\ for \\ The GAS CHARACTERIZATION SYSTEM (GCS)}

\subsection{INTRODUCTION}

The Gas Characterization System (GCS) Project was commissioned by TWRS management with funding from TWRS Safety, on December 1, 1994. The project objective is to establish an instrumentation system to measure specified gas concentrations in the vapor space of selected watch list tanks, starting with tank AW-101. Data collected by this system is meant to support first tank characterization, then tank safety. System design is premised upon Characterization rather than mitigation, therefore redundancy is not required.

The flammable gas watch-list (FGWL) tanks, have the greatest potential of releasing hydrogen and other combustible gasses approaching the lower flammability limit (LFL). Tanks which have had measured releases of hydrogen in excess of $0.75 \%$, by volume, require characterization in addition to that provided by the Standard Hydrogen Monitoring System (SHMS), to establish the actual LFL. Gas Characterization Systems will be fabricated and installed on these FGWL tanks to provide this characterization.

\subsection{SCOPE}

This document provides an itemization of the necessary GCS computer functions. To accomplish the envisioned goals, the GCS must service the functional requirements defined in this document.

\subsection{DESCRIPTION}

The Gas Characterization System (GCS) computer system consists of several individual computer components necessary to address the control and data acquisition functions of the several specific types of instruments used to monitor the vapor space. These computers are networked, using the Microsoft Windows $\mathrm{NT}^{\mathbf{2}}$ multi-tasking operating system, and networking software. This allows the system components to function in parallel and perform instrument and valve control, data collection, calculations and analysis, computer synchronization and interfacing, and archiving functions.

$r=$ Windows NT is a registered trademark of Microsoft Corporation 


\subsection{SOFTWARE REQUIREMENTS SPECIFICATION}

The Gas Characterization System requires computers to control and sequence the many instruments, sensors, and electric valves. Additionally, the computers must perform mathematical functions (ie. integrate the area under the curve) to produce "Calculated Concentrations". Control and sequencing of the valves and instruments, with these microcomputers, requires not only vendor supplied software, but also configuration, automation, and integration programming. This section will address the requirements, functions, inputs, outputs, and format associated with the GCS product.

At the beginning of the GCS project, the following criteria was established as necessary in relation to the GCS software:

4.1 The following vapor space gasses shall be monitored within the listed ranges.

$$
\begin{aligned}
& -\mathrm{H}_{2} \text { from } 0 \text { to } 30,000 \mathrm{ppm} \\
& -\quad \mathrm{NH}_{3} \text { from } 1 \text { to } 10,000 \mathrm{ppm} \\
& -\quad \mathrm{N}_{2} \mathrm{O} \text { from } 1 \text { to } 30,000 \mathrm{ppm} \\
& -\quad \mathrm{CH}_{4} \text { from } 0 \text { to } 30,000 \mathrm{ppm}
\end{aligned}
$$

4.2 The system shall be automated to provide continuous sampling and calculated data.

4.3 The system CPU shall be network connected for:

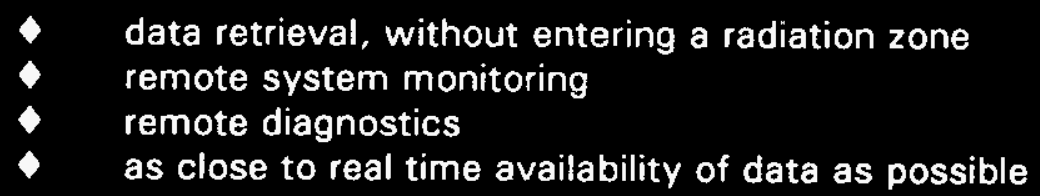

4.4 The system shall be reconfigurable to read other gasses (with some degree of software and hardware change)

4.5 The system shall selectively preserve spectral data ${ }^{\star}$ for future review

save all calibration data
save faulty data sets (0 data)

4.6 The Gas Chromatograph shall sample at a rate faster than once per 5 minutes.

4.7 The Fourier Transform InfraRed spectrometer (FTIR) sample rate, at 64 scans, shall be a minimum of 6 per hour.

4.8 The computer operating systems shall be compatible with the site standard and shall provide for preemptive multi-tasking. Windows $\mathrm{NT}^{\boldsymbol{2}} \mathbf{3 . 5}$ (or later version) is recommended. The software shall be Windows ${ }^{r} 3.11$, Wing $^{\circ}$, or Win $\mathrm{NT}^{\mathrm{r}}$ compatible.

\footnotetext{
$r=$ Windows, Win NT, and Win95 is a registered trademark of Microsoft Corp.
} 
4.9 System software shall control calibrations and flag them in the data set.

4.10 The calculated concentrations file and the associated spectral data files, shall be given unique record names based upon the date. Each record of the calculated concentrations file shall contain both a date and time stamp.

4.11 Process data (such as pressure, flow, $\&$ temperature) shall be logged at one minute intervals. Input channels shall be denoted in the saved data, and the records shall be identified by date and time. Each process data file shall be uniquely named using a date stamp.

4.12 Each computer controlling a directly connected instrument shall save necessary data for a minimum of 24 hours, in the event of a failure of another part of the system.

4.13 The GCS host computer (local to the instruments) shall preserve data for a minimum of one week, in the event of a failure of the central archival system (LABHOST) or related telecommunications.

4.14 No data shall be deleted from the local system without verifying the data is resident on the receiving computer.

4.15 Files containing the calculated concentrations and selected spectral data, shall be archived for long term availability.

4.16 After release of the developed integration software and the vendor supplied software, a formal change control process will be necessary, prior to making production software changes.

Notes:

Selectively Preserve Spectral Data -- is referring to the archival retention of data denoting significant data, changes, calibrations, and errors. Retention of routine data which may remain the same for days at a time, is unnecessary.

Future Review - The need to retrieve the spectral data associated with significant calculated data is to be considered on the order of years. 


\subsection{SAFETY CLASSIFICATION}

The monitoring instruments and systems used for the Westinghouse Hanford Waste Gas Characterization System are designated Safety Class 3 (Payne - ref.A). The Safety Class 3 Equipment Classification level is for Systems and components that address the health and safety of facility workers and radioactive, chemical, or thermal releases to the environment.

\subsection{REFERENCES}

A) Payne, M. A.,1994, "In-Tank Instrument Safety Classification", (Internal Memo, 9307342B R1, to R. E. Gerton, October 14, 1993), Westinghouse Hanford Company, Richland, Washington. 


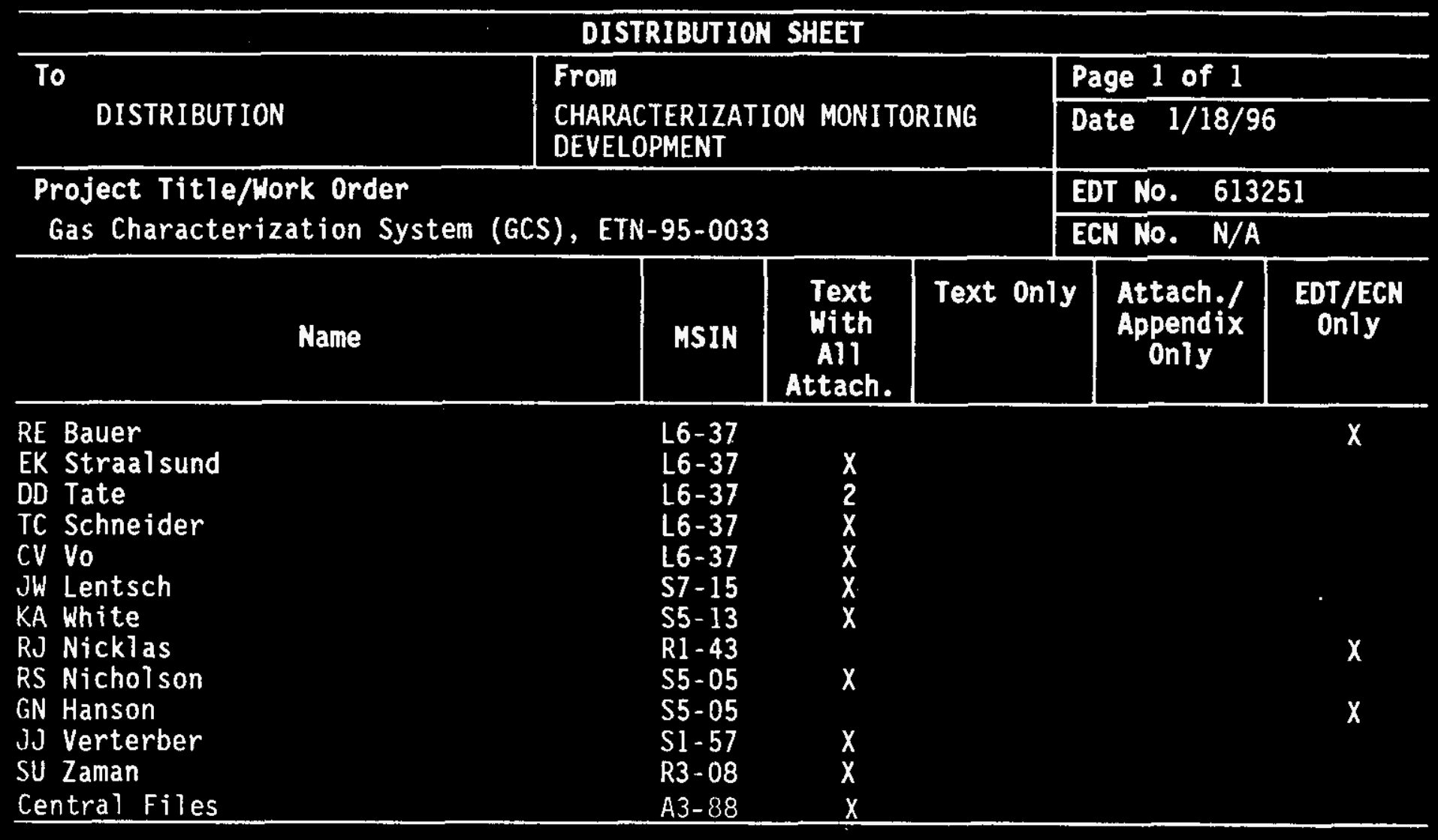

